\title{
PSIKOLOGI TOKOH UTAMA DALAM NOVEL DILAN, DIA ADALAH DILANKU 1991 KARYA PIDI BAIQ
}

\author{
${ }^{1}$ Karninik, ${ }^{2}$ Siti Lamusiah, ${ }^{3}$ Sri Maryani \\ ${ }^{1,2,3}$ Pendidikan Bahasa Indonesia, Universitas Muhammadiyah Mataram, Indonesia \\ karninik2030@gmail.com, maryanisri218@gmail.com
}

\section{INFO ARTIKEL}

\section{Riwayat Artikel:}

Diterima: 10-05-2019

Disetujui: 30-07-2019

\section{Kata Kunci:}

Psikologi Kepribadian, Id.

Ego, Superego, Novel Dilan 1991.

\section{Keywords: \\ Personality Psychology, id, ego, superego, Dilan 1991 novels}

\begin{abstract}
ABSTRAK
Abstrak: Penelitian psikologi sastra memiliki peran penting dalam memberikan umpan balik dalam perwatakan yang dikembangkan dalam menganalisis karya sastra yang kental dengan masalah psikologis. Dalam psikosastra, konflik merupakan pergejolakan antara id, ego dan superego. Ketiga hal tersebut dapat ditemukan dalam sebuah karya sastra melalui tokoh-tokoh yang ditampilkan pengarang. Penelitian ini bertujuan untuk mendeskripsikan unsur psikologi id, ego dan superego pada tokoh utama dalam novel Dilan, Dia Adalah Dilanku Tahun 1991 Karya Pidi Baiq. Metode pengumpulan data yang digunakan adalah deskriptif kualitatif. Metode analisis data berupa identifikasi data, klasifikasi data dan penarikan kesimpulan. Hasil penelitian menemukan unsur id, ego dan superego. Unsur psikologi id tokoh Milea yaitu id Milea memenuhi kepuasan, memenuhi kesenangan, menolak ketidak nyamanan yaitu berbohong, id Milea menangis karena memutuskan hubungannya dengan Dilan, id Milea untuk memenuhi rasa ngantuk,id Milea menolak rasa tidak nyaman. Unsur psikologi ego tokoh Milea yaitu, menggambarkan tentang mengendalikan keputusan, bentuk penalaran dalam mengambil keputusan, menyelesaian masalah. Selanjutnya unsur psikologi Superego dikelompokan ke dalam kelompok benar dan salah, hati nurani, serta merintangi dorongan id yaitu tindakan Milea yang bertingkah laku ramah, hati nurani yang merasa bersalah.
\end{abstract}

\begin{abstract}
Literary psychology research has an important roles in characterization prividing which was developed in analyzing literary works that are thick with psychological problems. in psychology, conflict is a struggle between the id, the ego and the superego. these three things can be found in a literary work through the characters displayed by the author. The aim of this research are to describe the psychological elements of the id, ego and superego to the main character in the dilan novel, Dia Adalah Dilanku 1991 bye pidi baiq. the data collection method used is descriptive qualitative. Data analysis methods included the data identification, data classification, and conclusion. the results of the study found the elements of id, ego and superego. psychologies element id milea are id milea has satisfaction, satisfies pleasure, refuses discomfort that is lying, id milea cries because she decides her relationship with dilan, id milea to satisfy drowsiness, id milea refused discomfortable feels. Psychology elements of milea's ego characters are, describes about controlling decisions, solving problems. then the elements of superego psychology are grouped into groups of right and wrong, conscience, and hinder the id's encoragement that is the act of milea who has kindly characters, feels conscience guilty.
\end{abstract}

\section{A. LATAR BELAKANG}

Pada hakikatnya karya sastra merupakan hasil pemikiran seseorang tentang pengalaman hidup yang dirasakan atau dilihat. Hasil pemikiran tersebut kemudian dituliskan sehingga membuat pembaca seolah-olah merasakan apa yang dialami dalam sebuah cerita tersebut. Karya sastra adalah dunia rekaan yang realitas atau faktanya telah dibuat sedemikian rupa oleh pengarang. Karya sastra dapat 
dibagi menjadi dua, yaitu karya sastra imajinatif (fiksi) dan nonimajinatif. Karya sastra imajinatif adalah karya sastra yang dibuat berdasarkan imajinasi atau khayalan yang diambil dari refleksi kehidupan. Sedangkan sastra nonimajinatif adalah sastra yang dibuat berdasarkan fakta dan kenyataan yang terjadi.

Dalam psikosastra, konflik merupakan pergejolakan antara Id, Ego dan Superego. Ketiga hal tersebut dapat ditemukan dalam sebuah karya sastra melalui tokoh-tokoh yang ditampilkan pengarang. Id merupakan dorongan yang sifatnya biologis dan dibawa sejak lahir. Id tidak mengenal aturan-aturan yang ada dalam masyarakat. Maka untuk mengendalikannya diperlukan Ego. Ego adalah pengendali agar manusia bertindak dengan cara yang benar dan bersifat rasional. Superego merupakan penentu perilaku seseorang yang dibetuk dari pembudayaan dan pendidikan.

Peneliti akan meneliti psikologi tokoh utama pada novel Dilan, Dia Adalah Dilanku Tahun 1991 Karya Pidi Baiq yang menjadi tokoh utama dalam novel tersebut yaitu Milea yang menceritakan kisah cinta, seorang gadis cantik pindahan dari Jakata dan kisah ini menceritakan kisah konflik saat-saat mereka pacaran, perubahan tingkah laku yang signifikan terjadi pada tokoh utama. Milea awanya pemalu tepi berubah menjadi keras kepala karena didorong oleh keinginan-keinginan Milea untuk merubah Dilan.

Melalui kisah di atas banyak kalangan yang kontra dengan cerita kisah novel ini karena tidak sesuai dengan norma agama dan pendidikan, kisah tersebut secara tidak langsug mengajarkan remaja sekarang untuk bagaimana makna pacaran yang sebenarnya. Banyak remaja Indonesia sekarang sudah berpengaruh pada persoalan novel ini bahkan sudah tergeser cara berpikir dan moralitasnya sudah menurun, sehigga tidak heran di media sosial ada adegan-adegan yang tidak pantas untuk ditiru. Namun disisi lain novel ini mengajarkan kita untuk menghargai setiap karya orang lain. Nilai moralnya, walaupun Dilan anak yang sering berkelahi, bahakan sering di skors dari sekolah, namun Dilan digambarkan sebagai seorang yang menghormani orang tua, bahakan wali kelasnya yang sering menegurnya pada saat dia salah. Selanjutnya, kelompok geng motor memilki kesan yang buruk dalam pemikiran masyarakat, tapi pada kenyataanya banyak disenangi orang dan mempunyai banyak teman.

Jadi berdasarkan uraian yang dipaparkan di atas, peneliti akan melakukan analisis terhadap struktur psikologi kepribadian tokoh utama yang terdapat dalam novel Dilan, Dia adalah Dilanku Tahun 1991 karya Pidi Baiq. Penelitian ini bertujuan untuk menganalisis psikologi kepribadian yaitu Id, Ego dan Supergeo tokoh utama dalam novel Dilan, Dia adalah Dilanku Tahun 1991 karya Pidi Baiq melalui pendekatan psikologi sastra.

\section{B. METODE PENELITIAN}

\section{Membaca Teks}

Membaca teks berita dari awal untuk menemukan data yang menunjukan keberadaan penyebab frustrasi. Namun, menyadari plot cerita tidak murni (tidak urut) alias regressive (flash back), pelacakan penyebab frustrasi tidak dilakukan di halaman awal. Data penyebab ada pada halaman berikutnya, yakni halaman 1655 dan 1659. Seterusnya ia beri tanda apapun di sekitar kalimat yang mengisyaratakan keberadaan penyebab frustrasi. Hal ini untuk mempermudah peneliti pada saat mengecek ulang.

\section{Melakukan Pencatatan (hand writing).}

Selanjutnya ia catat satu persatu data tersebut di kartu pengumpulan data dengan disertai kode.

\section{Memberi Deskripsi (Eksplinsit dan Implisi)}

Setelah mencatat data, peneliti memberi deskrisi (penjelasan) seperti: setting (latar tempet dan waktu) peristiwa, peristiwa khusus yang melatari data, perilaku tokoh. Deskripsi ditulis di lembar pengumpulan data lain. Deskripsi bisa ditulis panjang atau sigkat tetapi tetap merujuk kepada teks cerita. Ia berperan sangat bersignifikan di dalam menuntut peneliti menyusun data ke dalam paparan pada saat memasuki kegiatan data display. Dengan kata lain kombinasi data dan deskripsi inilah yang membentuk laporan analisis data. Selain itu, deskripsi berperan sangat vital di dalam upaya peneliti mempertajam keberadaan data yang telah dikumpulkan sehingga diperoleh data yang semakin meyakinkan, menurut Siswantoro, 2005: 138-139. 


\section{HASIL PENELITIAN}

\section{Biografi Pengarang}

Pidi Baiq adalah seorang seniman dan novelis serta merupakan salah satu aktor dibalik kesuksesan film Dilan. Pria kelahiran Bandung ini sudah memasuki usia 46 tahun, tepatnya lahir di Bandung, Jawa Barat, 8 Juli 1972. Karya yang dia miliki sebagai penulis sejak ini sudah banyak diminati, yaitu cerita pertama yang dia buat adalah Kumpulan Kisah Tidak Teladan dan karya lainya, keluarga Besar Kisah-kisah Non Teladan, Ikatan Perkumpulan Cerita Teladan, serta karya yang telah peneliti teliti yaitu novel Dilan, Dia Adalah Dilanku Tahun 1991. Peneliti tertarik untuk untuk menganalisis novelnya Dilan, Dia Adalah Dilanku Tahun 1991, karena cerita dalam novel ini menceritakan tentang sepasang kekasih yang seling ego dalam mengambil keputusan dan konflik batin yang memuncak.

Banyak orang tertawa dan kebaperan ketika membaca karyanya, termasuk cerita novel Dilan 1 dan Dilan 2 yang saat ini digemari oleh kalangan remaja. Nama Pidi Baiq awanya hanya terkenal melalui novel yang ia karang tapi sekarang sudah semakin lebih terkenal lagi karena namanya diangakat dalam sebuah film, salah satunya film Dilan episode 2 yang peneliti analisis. Bahkan Pidi merupakan seorang seniman yang dirasa komplit karena selain Pidi mahir dalam menulis Pidi juga merupakan seorang musisi, Pidi mahir dalam menuangkan ide-idenya kedalam sebuah lagu. Pidi Baiq membuktikan keseriusannya dalam dunia musik dengan membuat sebuah Band yang di berinama The Panas Dalam band tersebut merupakan band yang sangat hits dimasanya. Namanya mulai dikenal melalui grup band The Panas Dalam tersebut yang didirikan tahun 1995.

\section{Sinopsis Novel}

Cerita ini mengisahkan sepasang kekasih anak SMA yaitu Dilan dan Milea, jatuh cinta mada masamasa sekolah pada waktu dimana para remaja mulai mengenal apa itu cinta. Peran utama dalam novel seri kedua ini adalah Milea, menceritakan kembali kisah masa lalunya bersama Dilan baik itu waktu SMA maupun setelah SMA, Milea awalnya gadis kalem, lugu dan polos tapi semenjak mengenal Dilan dia berubah karena kisah asmara yang diikat oleh seorang laki-laki yang ia cintai, terkena oleh virus cinta yang indah yang disebarkan oleh Dilan yaitu laki-laki yang Milea sebut panglima perang, Dilan adalah laki-laki nakal yang pertama kali Milea kenal yaitu setiap hari suka berantam bahkan Bundanya pun sering memarahinya, suka keliaran dengan geng motor, tapi anaknya pintar, berbakti pada orang tua, pendiam, suka gombal dan setia. Semester terakhir SMA mereka resmi berpacaran dengan tanda tangan di atas matrei. Milea kembali mengisahkan kenangan indahnya bersama Dilan. Di warung Bi Eem, akhirnya Dilan dan Milea pun resmi berpacaran lengkap dengan surat pernyataan yang mereka tanda tangani di atas materai. Layaknya pasangan yang baru jadian, keduanya melewati hari-hari dengan penuh warna. Dilan dengan setia menelpon dan menjemput Milea, bahkan membawa Milea jalan-jalan dengan motornya. Walaupun diterpa guyuran hujan mereka tetap tertawa riang. Milea merasa begitu bahagia, aman dan senang dengan keberadaan Dilan. Setiap hari Milea selalu rindu akan Dilan. Namun hari-hari indah itu tidak berlangsung lama. Cinta mereka langsung diuji. Berbagai konflik pun mulai bermunculan.

Pada novel sebelumnya, Dilan pernah menghajar Anhar karena telah lancing menyakiti dan menampar Milea hingga menangis. Akibat keributan tersebut Dilan dan Anhar terancam dikeluarkan dari sekolah apabila berkelahi lagi. Milea mengerti bahwa yang dilakukan oleh Dilan semata-mata untuk melindunginya. Namun tidak dapat dipungkiri bahwa pada sisi lain Milea juga khawatir apabila Dilan berkelahi lagi karena dirinya, terlebih Dilan masih bergabung dengan geng motornya. Benar saja, suatu hari Dilan dikeroyok di warung Bi Eem. Milea langsung menemui Dilan dan bertanya berkelahi dengan siapa. Namun Dilan hanya menjawab, "Agen CIA." yang ternyata kakaknya Anhar. Milea pun kesal sekaligus khawatir dengan kekasihnya tersebut. Perdebatan antara Dilan dan Milea pun kian sering terjadi, terlebih tentang masalah geng motor. Dilan tidak pernah merasa kapok bahkan gengnya berencana untuk melakukan balas dendam atas pengeroyokan Dilan tempo hari. Hal ini tentu saja membuat Milea merasa takut dan khawatir dengan keselamatan kekasihnya itu. Dilan yang cenderung tidak ingin dikekang tetap tidak mengindahkan nasihat Milea. Milea mengancam Dilan untuk putus apabila Dilan masih tidak nurut. Hingga pada akhirnya Milea memergoki Dilan dan geng motornya untuk melakukan serangan balik kepada kakaknya 
Anhar. Milea pun mengatakan putus disusul dengan tamparan pada wajah Dilan. Putusnya hubungan keduanya ini tentu sangat menyakiti hati kedua belah pihak. Dilan sangat mencintai Milea, begitupun sebaliknya. Tapi bagaimanapun juga Milea tidak ingin sesuatu yang buruk terjadi pada Dilan hanya karena dirinya. Sejak peristiwa tersebut, Dilan menjauh dari Milea. Jarak diantara mereka pun semakin jauh. Walaupun demikian, hati Milea tetap sama, hanya untuk Dilan. Hingga pada akhirnya Milea pun kembali ke Jakarta untuk kuliah di sana. Sedangkan Dilan sendiri kuliah di salah satu Universitas ternama di Bandung.

Semakin lama kabar tentang Dilan tidak terdengar lagi, seolah menghilang begitu saja. Milea terus berusaha untuk bisa menghubungi Dilan. Namun hasilnya selalu nihil. Bahkan kabar yang Milea dapatkan adalah keluarga Dilan sudah pindah rumah sehingga Milea pun kehilangan jejak Dilan. Milea pun kemudian bertemu dengan Herdi, kakak angkatan di universitasnya. Sosok Herdi mulai mengisi hari-hari Milea. Keduanya pun melangkah menuju jenjang pernikahan. Walaupun demikian, Dilan selalu ada di hati Milea dan Milea pun tetap mencintai Dilan. Pada akhirnya, Dilan pun dikabarkan sudah memiliki kekasih baru. Kisah cinta mereka di tahun 1990-an akan selalu terkenang pada keduanya dan tidak akan terhapus begitu saja.

\section{Analisis psikologi tokoh utama dalam novel Dilan, Dia Adalah Dilanku Tahun 1991 Karta Pidi Baiq}

\section{a. Id}

Id merupakan energi psikis dan naluri yang menekankan manusia agar memenuhi kebutuhan dasar atau bawaan seperti, menolak rasa sakit atau tidak nyaman. Menurut Freud, id berada di alam bawah sadar, tidak ada kontak dengan realitas. Cara kerja id berhubungan dengan prinsip kesenangan, yakni selalu mencari kenikmatan dan selalu menghindari ketidak nyamanan. Tokoh Milea yang merupakan tokoh utama dalam novel Dilan, Dia Adalah Dilanku Tahun 1991 ini mempunyai dorongan keinginan yang akan berujung pada rasa senang atau penolakan terhadap ketidak nyamanan yang ia rasakan serta tokoh Milea juga mempunyai dorongan untuk memenuhi kebutuhan biologisnya.
Id Milea memenuhi kepuasan, mencari kesenangan, menolak ketidak nyamanan dengan berbohong. Milea tidak ingin Bunda mengetahui hal yang sudah terjadi diantara dia dengan Dilan. Milea takut Bunda tambah kesal dan sedih.

"Pas kau jumpa, apa Dilan bilang?"

Aduh! Gak nyangka Bunda akan nanya itu. Aku nggak siap menjawabnya sehingga gak tahu harus bilang apa karena gak mungkin juga aku cerita tentang kejadian sebenarnya bahwa di sana, di rumah Burhan, sejak itu aku sudah putus dengan Dilan. Jadi, aku merasa harus berbohong ke Bunda. Aku tak ingin membuat Bunda kecewa karena kukira dia sangat senang ketika tahu Dilan berpacaran denganku. Jika memang harus bilang, tapi tapi aku merasa saat itu bukan waktu yang tepat.

"Ya, ngomong biasa aja, Bunda."

Bunda mendesah, seperti sedang melepaskan rasa kesalnya." (hlm. 300)

Kutipan di atas adalah kata hati Milea untuk memenuhi id, ketika Bundanya Dilan menanyakan Pada Milea apakah tadi Milea berjumpa dengan Dilan ada sesuatu yang dibicarakan, tapi Milea berbicara dalam hati bahwa tidak mungkin dia membicarakan hal yang terjadi di rumah burhan tadi mengenai Milea dan Dilan putus karena Milea merasa takut kalau Bundanya Dilan tahu persoalan itu, karena bundanya Dilan merasa sangat senang kalau Milea berpacaran dengan Dilan. Jadi Milea harus berbohong pada Bunda yaitu tidak member tahukan kejadian tersebut, kalaupun Milea ingin cerita tidak mungkin, karena waktu itu bukan waktunya juga untuk menceritakan hal tersebut. Pertanyaan Bunda, Milea hanya menjawab ngomong biasa-biasa aja dengan Dilan. Jadi ketika milea menolak rasa ketidak nyamananya Milea harus terpaksa membohongi Bunda agar situasi menjadi aman dan tidak menambah beban Bundannya Dilan untuk berpikir keras.

\section{b. Ego}

Tugas ego memberi tempat pada fungsi mental utama, missal: penalaran, penyelesaian masalah dan pengambilan keputusan. Ego menolong manusia untuk mempertimbangkan apakah ia dapat memuaskan diri tanpa mengakibatkan kesulitan atau penderitaan bagi dirinya sendiri. 
Ego Milea yang mengendalikan keputusan. Ego memilih stimuli yang mana yang hendak direspon dan insting mana yang dipuaskan sesesui dengan perioritas kebutuhan. Dengan kata lain ego berusaha memenuhi kebutuhan id sekaligus juga memenuhi kebutuhan moral dan kebuthan berkembang mencapai kesempurnaan dari superego. Ego Tokoh Milea berusaha mengendalikan id dengan mengabil keputusan atau dengan memenuhi id. Hal tersebut terlihat seperti kutipan berikut:

Ketika acara pemakaman selesai, Dilan mengajak aku pulang bareng naik motornya, tapi aku bilang aku mau ikut rombongan mobil Nandan.

"Iya," katanya, kukira dia kecewa meskipun tidak kulihat dari wajahnya.

Akhirnya, Dilan pergi duluan. (hlm. 291)

Kutipan di atas menunjukan bahawa ada unsur ego, ketika Milea diajak pulang bareng naik motor oleh Dilan, Milea menolak berusaha memenuhi kebutuhan id karena Milea berpikir bahwa ketika dia setuju untuk barengan berarti dia menunjukan keputusan sikap tidak marah, oleh karena itu Milea tetap memaksa menolak ajakan Dilan agar Milea terlihat marah. Dilan hanya bisa menjawab "iya" tidak ada rasa kecewa, pada hal yang sebenarnya Milea inginkan agar Dilan bisa respon dengan tindakan dan sikap Milea tunjukan.

\section{c. Superego}

Superego yang mengacu pada moralitas dalam kepribadian. Superego sama halnya dengan 'hati nurani' yang mengenali nilai baik dan buruk (consciese). Meski Milea Awalnya kalem dan berubah menjadi beringas semenjak Milea Berpacaran dengan Dilan dan keras kapala serta seperti tidak ingin kalah dengan yang lainya, namun Milea memiliki sifat yang begitu baik walaupun hanya sekedar minta maaf.

Superego Milea tentang hal yang baik dengan bertingkah laku ramah. Perilaku Milea menunjukan ciri dari superego yaitu kebenaran nilai-nilai budaya dalam masyarakat dengan bersikap ramah kepada orang yang ditemui. Hal ini terlihat dari kutipan teks berikut:

"Habis itu, Tante Anis mengajak aku, Ayah, Ibu, dan Airin untuk ikut ke Ciwidey. Katanya mereka akan menyewa villa untuk menyambut tahun baruan di sana.

"Aku minta maaf ke Tante Anis karena aku tidak bisa menerima tawaranya itu. Meskipun Ayah, Ibu dan Airin pergi, aku akan memilih untuk tetap gak ikut."(hlm. 246)

Sikap yang ditampilkan oleh Milea terhadap Tante Anis adalah ucapan meminta maaf karena tidak bisa memenuhi ajakannya untuk ikut ke Ciwidey bersama keluarga dan lebih memilih untuk tidak ikut. Superego yang muncul pada Milia di atas adalah ucapan meminta maaf jadi terkait dengan ucapan minta maaf merupakan alam kesadaran dan merupakan etika moral Milea yang menentukan benar atau salah suatu hal tertentu.

Berdasarakan teori psikologi yang dikembangkan oleh Sigmund Freud (dalam Albertine Minderop, 2011: 20-23), didapatkan hasil penelitian berupa psikologi kepribadian manusia pada tokoh utama yaitu Milea pada novel Dilan Dia adalah Dilanku Tahun 1991 Karya Pidi Baiq, yaitu unsur kepribadian id, ego dan superego. Pertama id, id Milea memenuhi kepuasan, mencari kesenangan, menolak ketidak nyamanan dengan berbohong, id Milea menangis karena memutuskan hubunganya dengan Dilan, id Milea untuk memenuhi rasa ngantuk dan id Milea menolak rasa tidak nyaman. Kedua ego, ego Milea yang mengendalikan keputusan, ego Milea bentuk penalaran dalam mengambil keputusan dan Ego Milea dalam menyelesaikan masalah. Ketiga superego, superego Milea tentang hal yang baik dengan bertingkah laku ramah dan superego Milea dalam hati nurani yang merasa bersalah.

\section{SIMPULAN DAN SARAN}

Berdasarkan hasil pengumpulan data dan hasil analisis data yang telah dilakukan, peneliti memukan tiga unsur psikologi tokoh utama berdasarkan teori Sigmund Freud yakni id, ego dan superego dalam tokoh utama Milea pada novel Dilan Dia Adalah Dilanku Tahun 1991 Karya Pidi Baiq. Unsur psikologi: Pertama, unsur Id yang terdapat dalam tokoh Milea digambarkan sebagai seorang yang penuh dengan keinginan di dalam dirinya. Keinginan yang asalmula hanya ingin mengetahui berubah menjadi keinginankeinginan lain yang berujung pada perbuatan Milea, 
yakni mencari kesenangan menolak ketidak nyamanan dan dorongan biologis. Kedua, unsur ego dalam penelitian ini dikelompokan ke dalam membuat keputusan dan pemenuhan kebutuhan $i d$. Milea sulit untuk menetralka keadakan ketika konflik memuncak jadi dia memutuskan diam. Ketiga, unsur superego yang dikelompokan ke dalam benar atau salah kata hati yang menghukum perilaku yang salah, serta merintangi dorongan $i d$. Rasa penyesalan yang dirasakan Milea dengan menghukum diri sendiri. Unsur psikologi yang dominan dalam tokoh utama novel Dilan Dia Adalah Dilanku Tahun 1991 Karya Pidi Baik adalah unsur Ego.

\section{REFERENSI}

Badrum Ahmad. 2005. Dasar-Dasar Psikologi Sastra. Mataram: Universitas Press.

Endraswara, Suwardi. 2003. Metodologi Penelitian Sastra.Yogyakarta: Pustaka Widyatama.

Harfuddin. 2011. Analisis Psikologi Tokoh Utama Dalam Novel Jalan Hikmah Menuju Cinta Karya Lin Yakub. Jurnal diakses $15 \quad$ Februari 2019. http://nurminabastra.Blogspot.com/2013/10/anal isis-psikologis-tokoh-utama-dalam.html.

Ihsan Abraham. 2017. Sruktur Kepribadian Tokoh Dalam Novel Surat Kecil Untuk Tuhan Karya Agnes Davonar. Universitas Kanjuruhan Malang. Jurnal keilmuan bahasa, sastra dan pengajaranya. Volume 3, nomor 1, hlm 55-63. Di akses 30 Juni 2019. http//:ejournal.umm.ac.id/index.php/kembara.index

Inderop, Albertine. 2005. Metode karakterisasi telaah fiksi. Yayasan Pustaka Obor Indonesia.

Minderop, Albertine. 2013. Psikologi Sastra."Karya Sastra, Metode, Teori, dan Contoh Kasus". Jakarta: Yayasan Pustaka Obor Indonesia.

Moleong, Lexy J. 2001. Metodologi Penelitian Kualitatif. Bandung: Remaja Rosdakarya.

Nurizzati, Bakhtaruddin, dkk.__Kepribadian Tokoh Utama Dalam Sebelas Patriot Karya Andrea Hirata: Kajian Psikoanalisis. FBS Universitas Negeri Padang. Di akses 30 Juni 2019. Email:ab3l_hyt@yahoo.com

Nuriyantoro, Burhan. 2013. Teori Pengkajian Puisi. Yogyakarta. Gadjah Mada University Press.

Siswantoro. 2005. Metode Penelitian Sastra, Analisis Psikologis. Surakarta: Muhammadiyah Universitas Press.

Susanto, Dwi. 2016. Penantar PKajian Sastra. Yogyakarta: CAPS. 